DOI: 10.17707/AgricultForest.62.4.03

Alexandra D. SOLOMOU, Elpiniki SKOUFOGIANNI ${ }^{I}$

\title{
ALPHA AND BETA PLANT DIVERSITY IN MULTISPECIES AGROECOSYSTEMS OF CENTRAL GREECE
}

\begin{abstract}
SUMMARY
Intercropping encourages biodiversity, by providing a habitat for a variety of plants, which benefit the population of insects and soil organisms that would not be present in a single-crop environment. The literature about this issue is scarce. Hence, the study of plant species density, alpha (species richness, Shannon, Simpson and Evenness index) and beta diversity (Jaccard similarity index) were held in the University of Thessaly facilities on May 2014, with the use of sample plot $(50 \times 50 \mathrm{~cm})$. The experimental plots were constituted of the following types of intercropping: Pea-Oats (P-O), Pea-Barley (P-B), Winter Vetch-Oats (WV-O), Winter Vetch-Barley (WV-B), Grass Pea-Oats (GP-O) and Grass Pea-Barley (GP-B). A total number of eight species of herbaceous plants were recorded in all types of intercropping. The average density of herbaceous plants was found significantly higher in the Pea-Barley $(21.80 \pm 13.68, \mathrm{p}<0.05)$ than the Pea-Oats $(10.00 \pm 7.61, \mathrm{p}<0.05)$, Winter Vetch-Oats $(10.60 \pm 17.79$, $\mathrm{p}<0.05)$, Winter Vetch-Barley $(6.80 \pm 9.47, \mathrm{p}<0.05)$, Grass Pea-Oats $(13.00 \pm$ $12.20, \mathrm{p}<0.05)$ and Grass Pea-Barley $(5.00 \pm 5.91, \mathrm{p}<0.05)$. The Shannon diversity index was higher in the Pea-Barley (1.33) and lower in Winter VetchOats (0.00), Winter Vetch-Barley $(0.00)$ and Grass Pea-Barley $(0.00)(\mathrm{p}<0.05)$. The results also showed that the type of intercropping Pea-Barley (1.00-0.85) favoured the evenness and similarity of plant species in relation to other types of intercropping $(\mathrm{p}<0.05)$. Conclusively, intercropping systems clearly have the potential to increase the long-term sustainability of food production under low inputs. Specifically, the type of intercropping Pea-Barley favours alpha and beta plant diversity making this type of intercropping important, favouring parameters of biodiversity both in Greek and in the wider Mediterranean areas. We conclude, also, on the need to enhance agricultural research on these multispecies systems, combining both agronomic and ecological concepts and tools.
\end{abstract}

Keywords: sustainability, crops, biodiversity, Mediterranean.

\section{INTRODUCTION}

Intercropping systems consist of two or more crops growing together and coexisting for a time. This final criterion distinguishes intercropping from mixed

\footnotetext{
${ }^{1}$ Alexandra D. Solomou,(corresponding author: alexansolomou@gmail.com),Hellenic Agricultural Organization "DEMETER", Institute of Mediterranean Forest Ecosystems, Terma Alkmanos, Ilisia, 11528, Athens, GREECE, Elpiniki SKOUFOGIANNI, Laboratory of Agronomy and Applied Crop Physiology, Department of Agriculture, Crop Production and Rural Environment, University of Thessaly, Fytokou str., 38446, N. Ionia, Magnisia, Volos, GREECE.

Paper presented at the $7^{\text {th }}$ International Scientific Agricultural Symposium "AGROSYM 2016".

Notes: The authors declare that they have no conflicts of interest. Authorship Form signed online.
} 
mono-cropping and rotation cropping ( $\mathrm{Li}$ et al., 2013; Brooker et al. 2015). Intercropping is common in countries with high amounts of subsistence agriculture and low amounts of agricultural mechanization. Intercropping is often undertaken by farmers practising low-input, low-yield farming on small parcels of land (Ngwira et al., 2012; Brooker et al. 2015).

Most studies on intercrops systems reporting legume-cereal intercropping, a productive and sustainable system, a resource facilitation which consist of growing, soil's fertility and yield. Latati et al. (2013) confirmed the advantage of intercropping legumes - cereals over sole cropping system, as sustainable agriculture.

The main advantage of intercropping is the more efficient utilization of the available resources and the increased productivity compared with each sole crop of the mixture (Agegnehu et al. 2008). Reversely, Ofori et al. (1987) indicated that intercropping system causes a decrease of yield due to the problems of harmful grasses, pests and diseases, in addition to the difficulties of harvesting.

Intercropping can conserve soil water by providing shade, reducing wind speed and increasing infiltration with mulch layers and improved soil structure (Young 1997). Spatial arrangement of intercrops is an important management practice that can improve radiation interception through more complete ground cover (Heitholt et al., 2005).

Intercropping of compatible plants also encourages biodiversity, by providing a habitat for a variety of plants, insects and soil organisms that would not be present in a single-crop environment. This in turn can help limit outbreaks of crop pests by increasing predator biodiversity (Altieri and Nicholls 2004). Plants form the critical base of food chains in nearly all ecosystems. Through photosynthesis, plants harvest the energy of the sun, providing both food and habitat for other organisms. Therefore, the study of plant diversity constitutes the key of the ecological balance in the intercropping ecosystems.

The literature about the above issue is scarce. Few studies have examined the role of plant functional diversity and the concept of overyielding in food production systems. Hence, the aims of this study is the estimation of plant species density and alpha diversity (species richness, Shannon, Simpson and Evenness index) in the following types of intercropping: pea-oats (p-o), peabarley (p-b), vetch-oats (v-o), vetch-barley (v-b), vetch-oats (v-o) and vetchbarley $(\mathrm{v}-\mathrm{b})$ providing environmental services that have impacts beyond the field scale, either spatially, e.g. services to the local or the global community, or temporally, e.g. modifications of the environment for future generations.

\section{MATERIAL AND METHODS}

A number of field experiments have been carried out in Thessaly plain (Experimental Farm of the University of Thessaly, Velestino, central Greece, 2014) with coordinates Lat: 390 23', Lon: $22^{\circ} 45^{\prime}$, and altitude 87.5 m (Fig.1). The soil at the site was a deep, moderately fertile, clay loamy soil that was classified as Calcixerollic Xerochrept (USDA, 1975). 


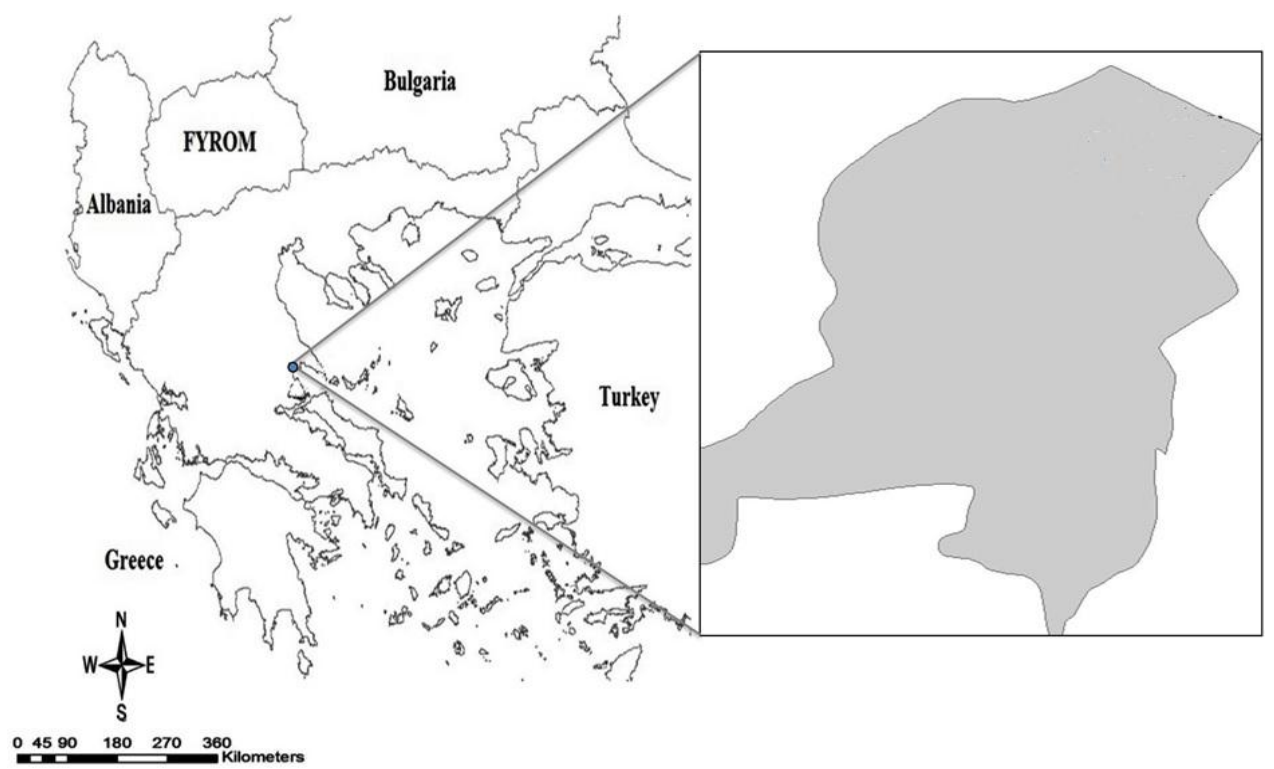

Figure 1. Study area

The study area is part of the Quercion ilicis and Oleo-Ceratonion subzones of the Quercetalia ilicis zone of the Mediterranean-type vegetation at altitudes up to $50 \mathrm{~m}$ a.s.l. (above sea level).

The climate in Greece is typical Mediterranean with cool humid winter and very dry and hot summer. Thessaly, the largest Greek lowland and the centre of the country's agricultural production, is characterized by a more continental climatic character with colder winters and hot summers.

\section{Sampling}

The sampling of herbaceous vegetation was carried out in May 2014 in randomly selected plots of $0.25 \mathrm{~m}^{2}$, in order to estimate plant density and diversity (Cook and Stubbendieck 1986, Solomou and Sfougaris 2013) (Fig. 2).

Data were evaluated for normality and homogeneity with the Kolmogorov-Smirnov and Shapiro-Wilk tests. Data were transformed using $\log (\mathrm{x}+1)$ when necessary to meet normality assumptions. For the analysis of plant data, a general linear model (GLM, Type III Sum of Squares) (one-way ANOVA) was used. Tukey's HSD (honestly significantly difference) pairwise comparison tests were used with $\mathrm{p}<0.05$. Statistical analyses were performed using the software package IBM SPSS Statistics ver. 19.0 for Windows (SPSS Inc., IBM Company, Chicago, IL, USA 2010).

Several alpha-diversity indices such as species richness, Shannon-Wiener, Simpson and evenness were calculated using Species Diversity and Richness IV software (comparisons among the type of intercropping systems were made with the randomization test of Solow (1993), Seaby and Henderson 2006). For a detailed description of the mathematical background of the above indices, see 
Seaby and Henderson (2006). A variety of methods for measuring beta diversity are available, among them similarity measures are the simplest and the most commonly used, being calculated from presence/absence data (Koleff et al. 2003). The similarity of plant communities among the types of intercropping systems was examined using the Jaccard index (Koleff et al. 2003) to express beta diversity, again using Species Diversity and Richness IV software (Seaby and Henderson 2006).
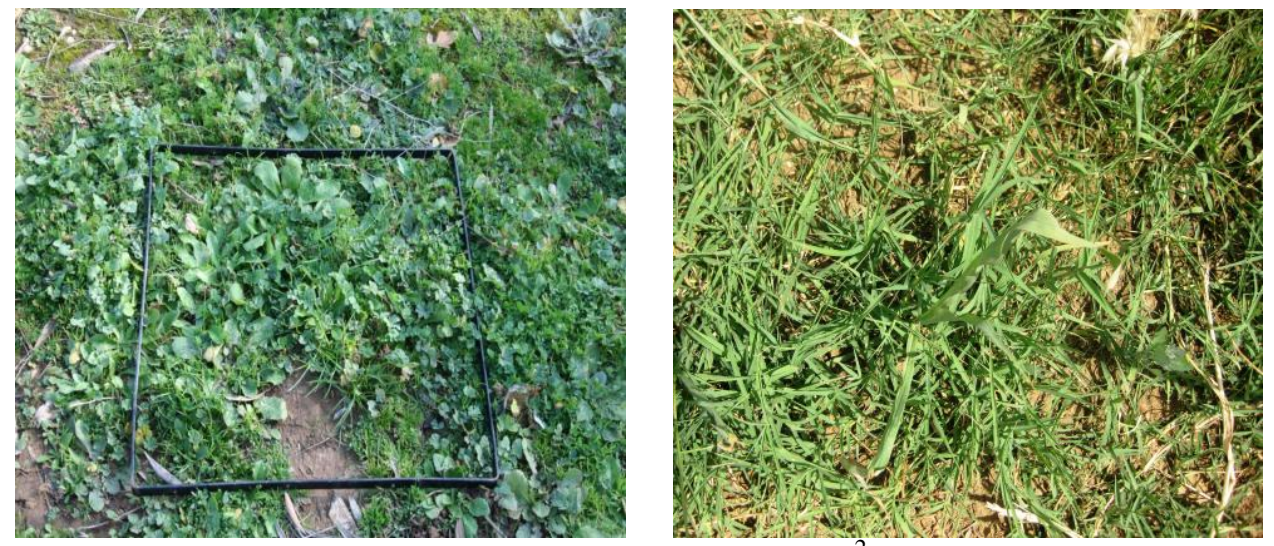

Figure 2. Sampling quadrate of $0.25 \mathrm{~m}^{2}(0.5 \mathrm{~m} \times 0.5 \mathrm{~m})$

\section{RESULTS AND DISCUSSION}

A total number of eight species of herbaceous plants were recorded in all types of intercropping in the study area [three (Pea-Oats), four (Pea-Barley), one (Winter Vetch-Oats), one (Winter Vetch-Barley), three (Grass Pea-Oats) and one (Grass Pea-Barley)] (Table 1). The highest mean density of herbaceous plants $(21.80 \pm 13.68$ individuals $/ \mathrm{m} 2, \mathrm{p}<0.05)$ (Figure 3) were recorded in the PeaBarley. Tengberg (Salas et al. 1997) indicates that diversity of agricultural systems, agricultural species and main species are three component of agrobiodiversity. Multiple cropping, especially intercropping, is one way to increase agroecosystems diversity (Marshall et al. 2003, Azizi et al. 2015).

Mohler, and Liebman (Mclaughlin and Minrau 1995) demonstrated that intercropping of barley and pea and barley monoculture were similar in plant species richness approximately. However, plant species richness in pea was the most (Mahn 1984, Mclaughlin and Minrau 1995, Azizi et al. 2015).

The type of intercropping pea-barley showed the highest similarity in plant species composition (table 1). Beta diversity is an important property of ecosystems because it provides information about the partitioning of habitats by species and constitutes an empirical and theoretical link between alpha (the local diversity of a community) and gama diversity (Cornell \& Lawton, 1992; Medianero et al. 2010). It captures a fundamental aspect of the spatial pattern of diversity, and its study is fundamental to understanding the geographic patterns of species richness (Whittaker, 1972; Koleff, 2005; Medianero et al. 2010). 
Table 1. Herbaceous plant species in the study area.

\begin{tabular}{|c|c|c|c|c|c|c|c|}
\hline \multicolumn{2}{|c|}{ Species } & Family & \multicolumn{5}{c|}{ Type of intercropping } \\
\hline \multirow{2}{*}{} & & $\begin{array}{c}\text { Pea- } \\
\text { Oats }\end{array}$ & $\begin{array}{c}\text { Pea- } \\
\text { Barley }\end{array}$ & $\begin{array}{c}\text { Winter } \\
\text { Vetch- } \\
\text { Oats }\end{array}$ & $\begin{array}{c}\text { Winter } \\
\text { Vetch- } \\
\text { Barley }\end{array}$ & $\begin{array}{c}\text { Grass } \\
\text { Pea- } \\
\text { Oats }\end{array}$ & $\begin{array}{c}\text { Grass } \\
\text { Pea- } \\
\text { Barley }\end{array}$ \\
\hline $\begin{array}{c}\text { Anthemis } \\
\text { arvensis }\end{array}$ & Asteraceae & + & + & & & & \\
\hline $\begin{array}{c}\text { Chrysanthemum } \\
\text { segetum }\end{array}$ & Asteraceae & & & & + & & \\
\hline $\begin{array}{c}\text { Sinapis } \\
\text { arvensis } \\
\text { Sinapis } \\
\text { alba }\end{array}$ & Brassicaceae & + & & & & & + \\
\hline $\begin{array}{c}\text { Convolvulus } \\
\text { arvensis }\end{array}$ & Convolvulaceae & + & + & & & & + \\
\hline $\begin{array}{c}\text { Papaver } \\
\text { rhoeas }\end{array}$ & Papaveraceae & & + & & & & \\
\hline $\begin{array}{c}\text { Avena } \\
\text { sterilis }\end{array}$ & Poaceae & & + & & & + & \\
\hline $\begin{array}{c}\text { Hordeum } \\
\text { murinum }\end{array}$ & Poaceae & & & + & & & \\
\hline
\end{tabular}

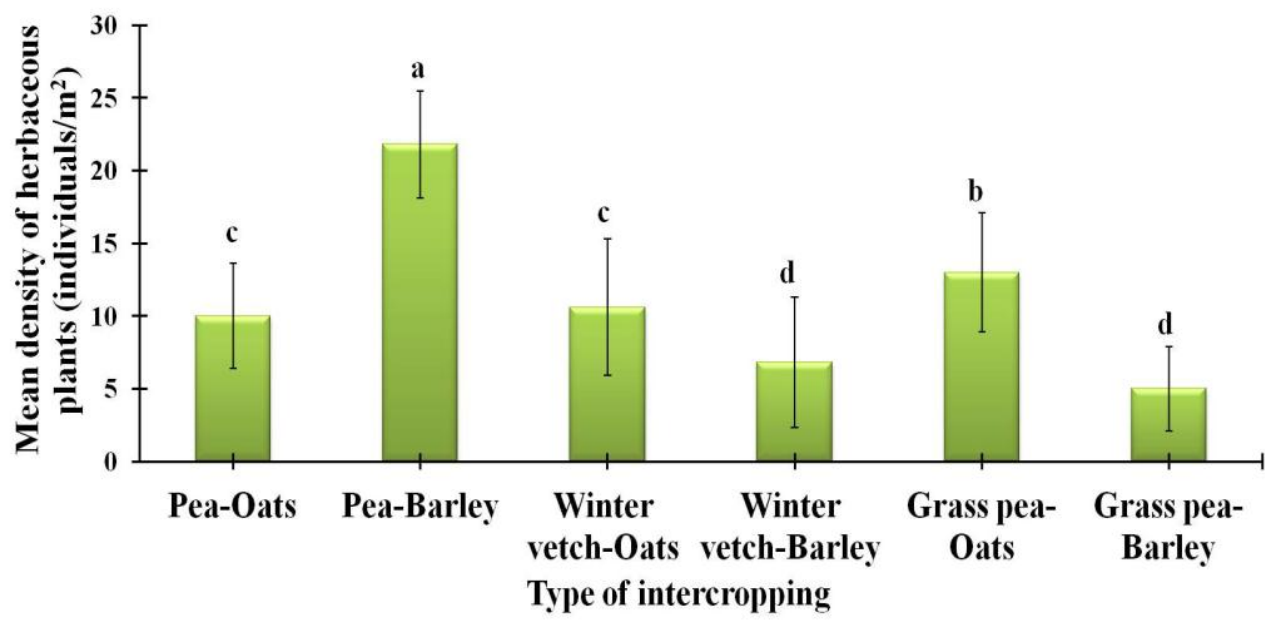

Figure 3. Mean density of herbaceous plants in all types of intercropping

Factors influencing species turnover among local fauna are usually a combination of environmental and geographical variables (i.e. Geographic distance) (Borcard et al. 1992), and determining their relative weighting is crucial for understanding the shaping of biogeographic patterns (Duivenvoorden et al. 2002, Medianero et al. 2010). 
Table 2. Alpha and Beta plant diversity in all types of intercropping.

\begin{tabular}{|c|c|c|c|c|c|c|}
\hline Index & \multicolumn{6}{|c|}{ Type of intercropping } \\
\hline $\begin{array}{c}\text { Alpha } \\
\text { diversity }\end{array}$ & $\begin{array}{c}\text { Pea- } \\
\text { Oats }\end{array}$ & $\begin{array}{c}\text { Pea- } \\
\text { Barley }\end{array}$ & $\begin{array}{c}\text { Winter } \\
\text { Vetch- } \\
\text { Oats }\end{array}$ & $\begin{array}{c}\text { Winter } \\
\text { Vetch- } \\
\text { Barley }\end{array}$ & $\begin{array}{c}\text { Grass Pea- } \\
\text { Oats }\end{array}$ & $\begin{array}{c}\text { Grass Pea- } \\
\text { Barley }\end{array}$ \\
\hline $\begin{array}{c}\text { Species } \\
\text { richness }\end{array}$ & 3 & 4 & 1 & 1 & 3 & 1 \\
\hline Shannon & 0.97 & 1.33 & 0 & 0 & 1.02 & 0 \\
\hline Simpson & 2.42 & 3.74 & 1 & 1 & 2.64 & 1 \\
\hline Evenness & 0.46 & 0.64 & 0 & 0 & 0.49 & 0 \\
\hline $\begin{array}{c}\text { Beta } \\
\text { diversity }\end{array}$ & \multicolumn{7}{|c|}{0} \\
\hline Jaccard & 0.86 & 0.91 & 0 & & 0.84 \\
\hline
\end{tabular}

\section{CONCLUSIONS}

Intercropping systems clearly have the potential to increase the long-term sustainability of animal food production under low inputs. Specifically, the type of intercropping - nitrogen symbiosis fixation by legume was used as important resource for intercropping during growing cycle of cultivated plants - in PeaBarley cultivation favours alpha and beta plant diversity making this type of intercropping important, favouring parameters of biodiversity both in Greek and in the wider Mediterranean areas.

\section{REFERENCES}

Agegnehu G, Ghizaw A, Sinebo W. (2008). Yield potential and land-use efficiency of wheat and faba bean mixed intercropping. Agron Sustain Dev 28:257-263.

Altieri M.A., Nicholls C. I. (2004). Biodiversity and Pest Management in Agroecosystems, Second Edition. Psychology Press.

Booker R., Bennett A., Cong W.F., Daniell T. J., George T.S., Hallett P.D., et al. (2015). Improving intercropping : a synthesis of research in agronomy, plant physiology and ecology. New Phytologist 206: 107-117.

Borcard D., Legendre P., Drapeau P. (1992). Partialling out the spatial component of ecological variation. Ecology 73:1045-1055.

Duivenvoorden J.F., Svenning J.C., Wright S. J. (2002). Beta diversity in tropical forests - response. Science 295: 636- 637.

Heitholt J. J., Farr J.B., Eason R. (2005). Plant configuration and cultivar environments. Crop Science 45: 1800-1808.

IBM SPSS Statistics. (2010). Statistical package for the social sciences (IBM SPSS Statistics) for

Windows, release 19.0.0.1. Chicago, IL: IBM SPSS Statistics.

Koleff P., Gaston K.J., Lennon J.J. (2003). Measuring beta diversity for presence-absence data. $\mathbf{J}$

Anim Ecol. 72:367-382.

Koleff P. (2005). Conceptos y medidas de la diversidad beta, p.19-40. In Halffer G, Soberón J, Koleff P, Melic A. (eds) El signifi cado de las diversidades alfa, beta y gama. Zaragoza, Sociedad Entomológica Aragonesa, 242p. 
Latati M., Pansu M., Drevon J.J., Ounane S.M. (2013). Advantage of intercropping maize (Zea mays L.) and common bean (Phaseolus vulgaris L.) on yield and nitrogen uptake in Northeast Algeria. International Journal of Research in Applied Sciences 1: 1-7.

Li L, Zhang L-Z, Zhang F-Z. (2013). Crop mixtures and the mechanisms of overyielding. In: Levin SA, ed. Encyclopedia of biodiversity, 2nd edn, vol, 2. Waltham, MA, USA: Academic Press, 382-395.

Mahn, E. G. 1984. Structural changes of weed communities and population. Vegetation. 58:79-85.

Marshall, E. J. P., Brown V. K., Boatman N. D., Lutman P. J. W., Squire G. R., Ward L. K. 2003. The role of weeds supporting biological diversity within crop fields. Weed Research. 43: 77-89.

Mclaughlin A., Minrau P. 1995. The impact of agricultural practices on biodiversity. Agriculture, Ecosystems and Environment. 55: 201-212.

Ngwira AR, Aune JB, Mkwinda S. (2012). On-farm evaluation of yield and economic benefit of short term maize legume intercropping systems under conservation agriculture in Malawi. Field Crops Research 132: 149-157.

Ofori F, Stern W.R. (1987). Cereal and legume intercropping systems. Advanced Agronomy 41: 41-90.

Respiration E. A., Alireza K., Parviz R.M., Mehdi N.M., Mansoureh-Sadat S.N. (2015). Evaluation of Plant Diversity and Nutrient Resource on Weed Diversity and Soil Microbial Agricultural and Biological Sciences Journal 5: 197-205.

Salas, M. L., Hickman M. V., Huber D. M., Schreiber M. M. (1997). Influence of nitrate and ammonium nutrition on the growth of giant foxtail (Setaria faberi). Weed Science. 45: 664 - 669.

Seaby R.M., Henderson P.A. (2006). Species diversity and richness Version 4.1.2. Lymington

(UK): Pisces Conservation Ltd.

Solow A.R. (1993). A simple test for change in community structure. J Anim Ecol. 62:191-193.

USDA. (1975). Soil Survey Staff, "Soil Taxonomy. A basic system of soil classification for making and interpreting soil surveys", Agric. Handbook 466, Washington DC, 754 pp.

Whittaker R.H. (1972). Evolution and measurement of species diversity. Taxon 21: 213251.

Young, J. (1997). Agro Forestry for Soil Management.CABI / ICRAF, Wallingford, UK.

Cornell H.V., Lawton J.H. (1992). Species interactions, local and regional processes, and limits to the richness of ecological communities: a theoretical perspective. J Anim Ecol 61: 1-12. 